\title{
ON THE CHRONOLOGY OF THE SABATYNIVKA GROUP OF THE CUCUTENI-TRYPILLIA CULTURAL COMPLEX (CENTRAL UKRAINE)
}

\begin{abstract}
Kiosak D. and Lobanova M. 2021. On the chronology of the Sabatynivka group of the Cucuteni-Trypillia cultural complex (Central Ukraine). Sprawozdania Archeologiczne 73/2, 25-46.

The paper discusses the dating of the Sabatynivka group of the Cucuteni-Trypillia culture. The authors have compared the sets of radiocarbon dates obtained for the sites of this group, analyzed the relative chronology, and checked the relationship of the dates for the Sabatynivka group with the dating of the contemporaneous cultural aspects. This approach has helped to establish the synchronism of the Sabatynivka group with the Skelia phase of the Seredny Stog culture, Gumelnița A2 and Cucuteni A3. The sites of the group existed during $44^{\text {th }}$ to $42^{\text {nd }}$ centuries BC.
\end{abstract}

Key words: Cucuteni-Trypillia, Radiocarbon dating, relative chronology, typological analysis, Skelia ware Received: 19.01.2020; Revised: 26.08.2021; Accepted: 10.11.2021

\footnotetext{
1 Department of Asian and North African Studies, Ca' Foscari University, Dorsoduro, 3246, 30123 Venezia VE, Italy; Odessa I.I. Mechnikov National University, Dvorianska str. 2, Odessa, Ukraine; dkiosak@ukr.net; ORCID: oooo-0002-3349-4989

2 PhD student of Odessa I.I. Mechnikov National University; lbnvmsh@gmail.com
} 


\section{INTRODUCTION}

In the last decade, new research has been shedding more light on the prehistory of Central Ukraine. The international projects aimed at the excavations and surveys of Trypillian mega-sites have produced considerable information about this region (Videiko et al. 2015; Müller et al. 2018; Chapman et al. 2019; Hofmann et al. 2019; Gaydarska et al. 2020). On the other hand, the phenomenon of Trypillian mega-sites will remain isolated without a detailed study of the previous stages of the development of the Trypillian culture. In this paper we discuss a group of sites of Trypillia culture of stage B1 (prior to the B1-B2 phase when mega-sites had appeared; Kotova and Videiko 2004). These sites form a densely settled microregion in the middle stretches of the Southern Buh river. Some sites are wellknown (Sabatynivka I, Berezivska HES), others have been discovered recently (Burdo 2015). The Trypillia B1 sites of the Sabatynivka microregion share some joint characteristics that make them different from other contemporaneous sites elsewhere in the CucuteniTrypillia cultural complex. An important point is that the Sabatynivka microregion is the easternmost enclave of the distribution of painted ware of the B1 phase. This work aims at establishing the chronology for the Sabatynivka group applying both ${ }^{14} \mathrm{C}$ dates (Kiosak et al. 2021; Lobanova et al. 2021) and typological analogies for the ceramic collections.

\section{SITES AND METHODS}

There are eight sites that are currently attributed to the Sabatynivka group. Some sites have been extensively excavated (Sabatynivka I, Berezivska HES), some were test-trenched (Kamyane-Zavallia I, Shamrai, Topoli, Kozachyi Yar I), others are known only from surveys (Kozachyi Yar II, Dovhyi Yar). The site of Kozachyi Yar II is completely destroyed by activities of a granite quarry and the archaeological remains are gathered in the re-deposited position (Peresunchak 2012). In 2013 and 2018-2019, a team from the University of Regensburg made a geomagnetic survey of the Kamyane-Zavallia I and Kozachyi Yar I sites (Saile et al. 2016b). Detailed research was carried out on five sites described in the following.

1. The Sabatynivka I site ( $48^{\circ} 9{ }^{\prime} 19^{\prime \prime N} ; 30^{\circ} 11^{\prime} 11$ "E) is located on a high promontory at the confluence point of rivers Southern Buh and Synytsia. It was found by S.I. Chub in 1929 and excavated by P. V. Kharlampovych in 1932, by O. V. Lagodovska in 1938 and A. V. Dobrovolsky in 1938-39, 1947-1948 (Dobrovolskyi 1952). The general excavated area is over $360 \mathrm{sq}$. m. The site bore remains of two cultural layers, at least. The lower layer included Trypillian materials, while the upper one is dated to the Late Bronze Age. The ceramic collection of the Trypillian layer contained over 3000 potsherds. It was published by T. S. Passek and A. V. Dobrovolsky (Passek 1949; Dobrovolsky 1952). Later on, E. K. Chernysh, I. V. Palaguta, N. B. Burdo treated the complex as a reference collection for the Sabatynivka group (Chernish 1982; Palaguta 2007; Burdo 2015). 


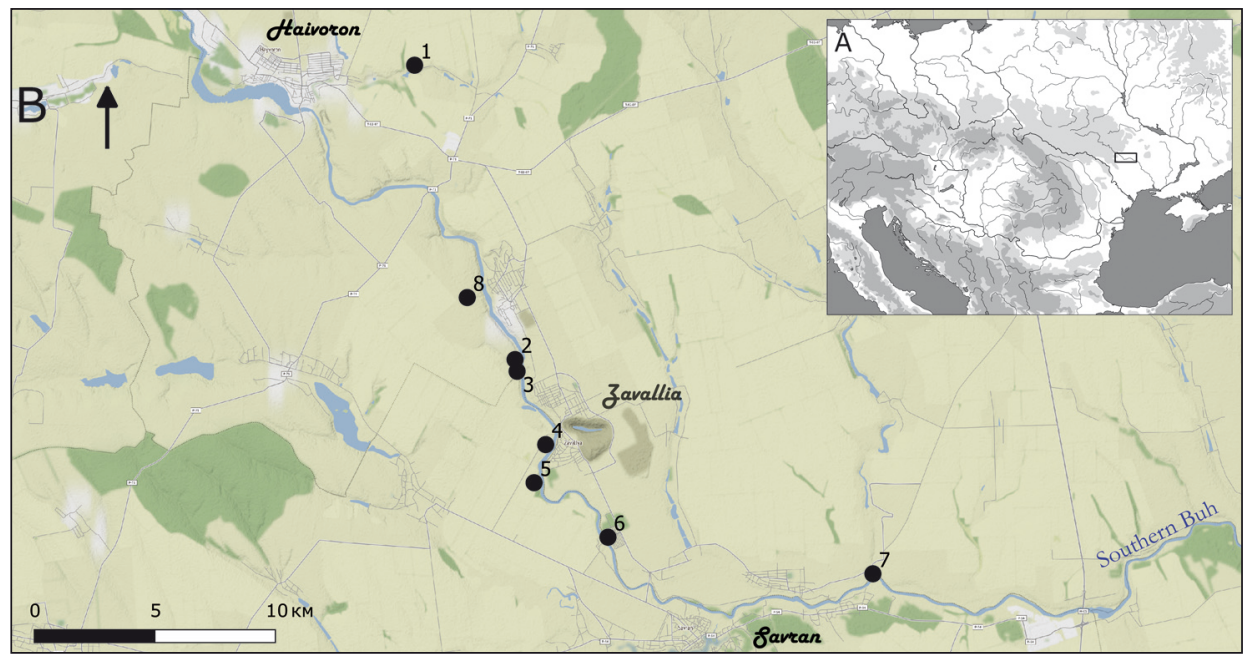

Fig. 1. Map. A: the Sabatynivka microregion on the map of Central Europe; B: the Sabatynivka group sites: 1 - Topoli, 2 - Kozachyi Yar 1, 3 - Kozachyi Yar 2, 4 - Kamyane-Zavallia I, 5 - Shamrai, 6 - Berezivska HES, 7 - Sabatynivka I, 8 - Dovhyi Yar. Topo - Stamen terrain USA/OSM

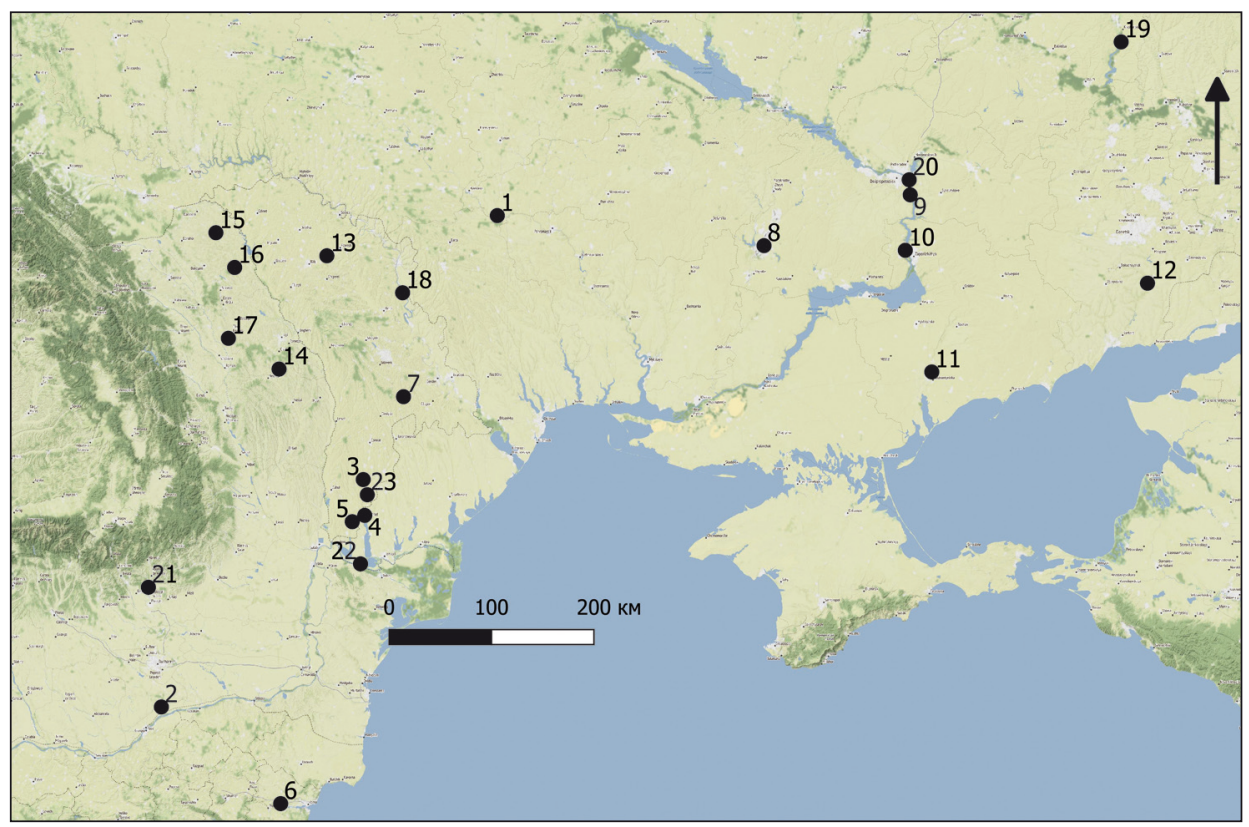

Fig. 2. Relations of the Sabatynivka group. 1 - the Sabatynivka group; 2 - Pietrele, 3 - Cealîc, 4 - Bolgrad, 5 - Vulcăneşti II, 6 Reka Devnia, 7 - Cainari, 8 - Kryvyi Rih, 9 - Strilcha Skelia, 10 - Seredny Stog, 11 - Semenivka, 12 - Rozdolne, 13 - Putineşti III, 14 - Scânteia, 15 - Drăguşeni-Ostrov, 16 - Truşeşti, 17 - Hăbăşeşti, 18 - Jura, 19 - Olexandria, 20 - Ihren VIII, 21 - Mălăieştii de Jos, 22 - Novoselske I, 23 - Taraclia I. Topo - Stamen terrain USA/OSM 
2. The Berezivska HES site ( $48^{\circ} 10^{\prime} 77^{\prime} \mathrm{N} ; 30^{\circ}$ ' $16^{\prime \prime} \mathrm{E}$ ) is on the left (northern) bank of Southern Buh river, just in $11 \mathrm{~km}$ to west from the Sabatynivka I site. It was investigated by V. M. Danilenko in 1958-1959, V. P. Tsybeskov in the 1960 s and by O. V. Tsvek in 19891999 (Tsvek 1999; Tsvek 2004). The site is the largest so far known settlement of the Sabatynivka group with a total area of 10 ha. V. P. Tsybeskov excavated seven dwellings. The researchers noted a prolonged period of site duration with several consecutive stratigraphic units. The ceramic assemblage includes painted potsherds in various styles of Cucuteni A (Dumitrescu 1963a; 1963b; Palaguta 2007, 47). The site yielded a huge collection of pottery, figurines, stone and flint implements. Unfortunately, this complex remains largely unpublished. Here, we use the small collection kept in the Zavallia secondary school and the collection from V. P. Tsybeskov's work from Odessa Archaeological Museum.

3. Kamyane-Zavallia $1\left(48^{\circ} 12^{\prime} 12 ” \mathrm{~N} ; 30^{\circ} \mathrm{O} ' 12\right.$ ” E) is situated on a flat promontory of the first terrace of right bank of the Southern Buh river. It was discovered by V. N. Stanko in 1974 (Stanko and Smolianinova 1974). In 2013, geomagnetic prospection covered the site's area (approximately 1,5 ha). The site consists of a large and undifferentiated "living zone" surrounded by two ditches (Dębiec et al. 2014; Saile et al. 2016a; Saile et al. 2016b). The site yielded ceramic groups with incised and stamped decorations as well as small potsherds with painted decoration indicative of the Trypillia B1 (Cucuteni A3) stage. The lithic inventory is dominated by small flat bifacial projectile points also characteristic for the developed Trypillia (Kiosak 2019). The figurines are covered with incised ornamentation (later type 2 of Zbenovich 1996). Two animal bones coming from filling of the inner ditch were selected for radiocarbon analysis (Kiosak et al. 2021).

4. The site of Shamrai ( $48^{\circ} 11^{\prime} 199^{\prime N} 29^{\circ} 59^{\prime} 50$ ”E) was discovered by O.S. Peresunchak (Peresunchak 2012). It is situated on a forested hill overlooking the high southern shore of the Southern Buh river. Here the slope is cut by a road bringing to light numerous bones, river shells and potsherds, probably remains of a destroyed pit (Kiosak 2016). An animal bone from remains of the pit was sampled (Kiosak et al. 2021).

5. The site of Topoli $\left(48^{\circ} 20^{\prime} 35^{\prime \prime N} ; 29^{\circ} 55^{\prime} 36^{\prime \prime E}\right)$ was also found by O.S. Peresunchak (Peresunchak 2015). It stands on the northern bank of a small stream flowing into the Southern Buh river. It yielded a notable surface collection of potsherds, throwing additional light on the results obtained from other sites from better defined contexts.

We applied the following methods to the selected sites. Small test trenches were opened in the sites of Sabatynivka I, Kamyane-Zavallia I, Shamrai. They were excavated with a refined stratigraphic control in order to secure the association of material remains and samples (animal bones) selected for ${ }^{14} \mathrm{C}$ dating (Kiosak et al. 2021). The new ceramic collections were studied by the traditional typological approach in order to define intercultural items that could shed a new light on the relative chronological position of the sites. In this work, we avoid discussing whether the intercultural items are imports or imitations. It is important that they were able to occur roughly simultaneously in various geographic points. 
A detailed re-examination of a similar design for older collections is underway for the sites of Sabatynivka I and Berezivs'ka HES (Lobanova et al. 2021). Animal bone samples were selected to re-date the site of Berezivs'ka HES too (Kiosak et al. 2021). The calibration and comparison of radiocarbon dates has been carried out with the OxCal software (Ramsey and Lee 2013). The comparative analysis of results between radiocarbon dating program and typological approach will validate and refine the supposed chronological position of the Sabatynivka cultural group.

\section{RESULTS}

\section{Absolute chronology}

The Neolithic and Eneolithic chronology of Ukraine has some important incongruences. The dates from Berlin, Kiel, Heidelberg, Leningrad, Oxford and some other laboratories cluster together with some dates of the Kyiv laboratory (mostly received prior to 1998 or after 2008), while several series of Kyiv dates, which were obtained in 1998-2008, are earlier by some 400 radiocarbon years (Telegin 1986; Telegin 1987; Rassamakin 2012; Gaskevych 2013; Gaskevych 2014).

A similar observation is true for the Sabatynivka group. The sites that were excavated in the 20th century (Sabatynivka I and Berezivska HES) obtained Kyiv dates (Burdo 2003) spanning between 4800-4401calBC (20). There were no non-Kyiv dates for the sites of the Sabatynivka group till now. However, the timespan cited above was significantly older than other dates which were made on the samples coming from the sites of analogous chronological position (Cucuteni A) from Romania and Moldova. Recently, the period Trypillia B1 was often dated to 4600-4050 BC (Mischka et al. 2016[2019]; Chapman et al. 2019) or 4600-4200 BC (Müller and Rassmann 2016).

Five dates from the LARA laboratory in Bern were obtained from animal bones from sites of Berezivs'ka HES, Kamyane-Zavallia I and Shamrai (Kiosak et al. 2021). They differ significantly (4341-4056 calBC; 20) from the dates that come from the Kyiv laboratory. Four dates can be combined (4332-4256 calBC, 20) and a single date (BE-7652, 5346 \pm 21 $\mathrm{BP}$ ) is slightly younger. The dates could be contemporaneous in the narrow time slot of 4328-4241 calBC (20).

The new dates contradict the Kyiv conventional dates and are in reasonable correspondence with the radiocarbon chronology of the Romanian sites of Cucuteni A (László 1997; Mantu 1998; Mantu 2000; Lazarovici 2010). Thus, a publication of these dates (Kiosak et al. 2021) creates a situation when the chronology of the Sabatynivka group needs to be revisited by means of typological analysis supported by comparison of radiocarbon dates. 


\section{Relative chronology}

The ceramic assemblage of sites of Sabatynivka type consists of several groups: 1) fluted thin-walled pottery with stamped lines, 2) a group with incised curvilinear decoration, 3) potsherds with shell temper and comb and pit ornaments, and 4) thin-walled, perfectly fired painted fragments of elegant small cups, 5) non-decorated fine ware, 6) coarse ware decorated by barbotine, appliques, impressed pits and wide flutes. The latter two groups are never numerous.

The first and the second groups form the major part of the assemblages $(68.8 \%$ in the collection of Sabatynivka I). They exhibit a notable variability and they constitute the cultural specificity of the Sabatynivka group. Some styles of decoration are limited to the sites of this microregion. Curvilinear fluted compositions surrounded by rows of stamp imprints are particularly characteristic in this aspect, because they are extremely rare in the sites of other territorial variants of Trypillia B1 period. The third and fourth group usually are not numerous (1-5\% of the collection, except Shamrai where the third group constitutes $22 \%$ of items). They find direct parallels and, sometimes, analogies (Palaguta 2007; Burdo 2015) in materials of Cucuteni A sites (fourth group) and in the settlements of the steppe mobile herders (third group). Some other, less obvious, "imports" probably link the Sabatynivka group with the Lower Danube sites of the Gumelnița culture (Burdo 2015).

The fourth group of the Sabatynivka ceramic complex (painted pottery) is made of very pure clay without any temper visible to the naked eye. It has very fine fabric and it was extremely evenly fired, resulting in a constant (light red or intense yellow) colour of outer and inner surfaces and in section. These sherds are found constantly in Sabatynivka group collections but in small numbers, sometimes just some items. They constitute $4.3 \%$ in Sabatynivka I, $1 \%$ in Topoli, and $4 \%$ in Shamrai.

Most potsherds are difficult to attribute to a certain group. Some others are decorated by curvilinear motives in black, red and white colours (Fig. 3: 4-8). White paint forms wide meandering stripes surrounded by thin black lines. I. Palaguta found parallels for these potsherds in Romanian sites of Cucuteni A, namely in Hăbăşeşti, Truşeşti, Bădragii Vechi and Darabani (Palaguta 2007, 47). He also noted the presence of the another decorative style in the upper layers of Berezivska HES - "multi-coil helixes". This resembles material from the settlement of Jura (Sorochin 2002). As far as it is known to the authors, there are no bichromic ("red on white") sherds in the Sabatynivka I site collection, contrary to previously reported information (Popova 2003, 56). Thus, the supposed early chronological position of Sabatynivka I is dubious, quite in line with the reported results of the radiocarbon dating on the other sites of the Sabatynivka group (Kiosak et al. 2021).

Recent finds include the upper part of a vessel from the Shamrai site (Fig. 3: 9). On the outer part it is decorated by a triangle going down from the very rim painted by black paint. From the inside it has a pattern of interchanging thin red lines, sometimes in stripes surrounded by black contour. The white paint is missing but it cannot be excluded that it 


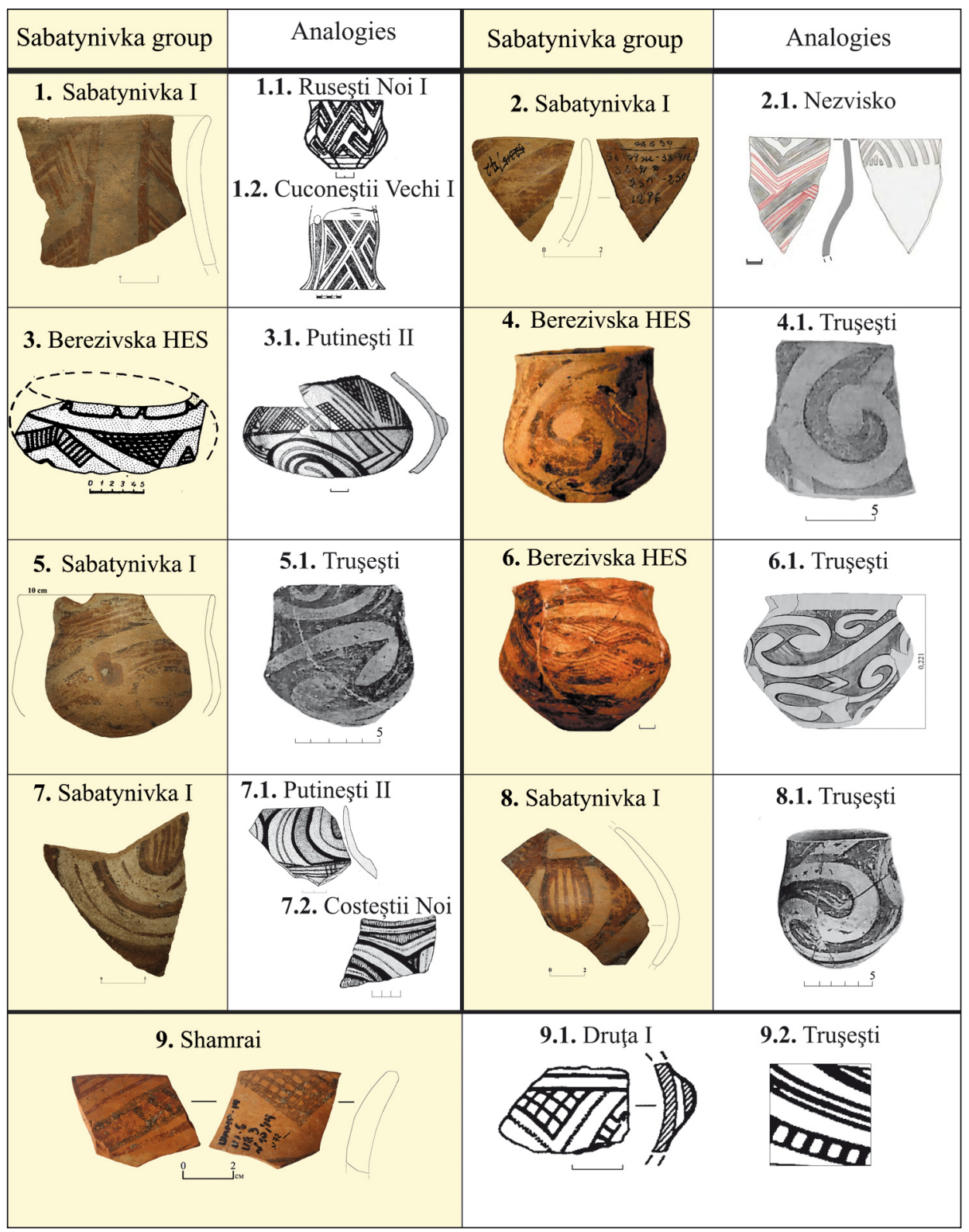

Fig. 3. Comparative table of Cucuteni $A$ and Sabatynivka group pottery

(1.1, 1.2, 9.1 by Palaguta 2016, 2.1 by Yakovyshyna and Kutseniak 2016, 3 by Tsybeskov 1965, 3,1, 7.1, 7.2 by Sorochin 2002, 4.1, 5.1, 6.1, 8.1, 9.2 by Petrescu-Dîmbovița et al. 1999) 


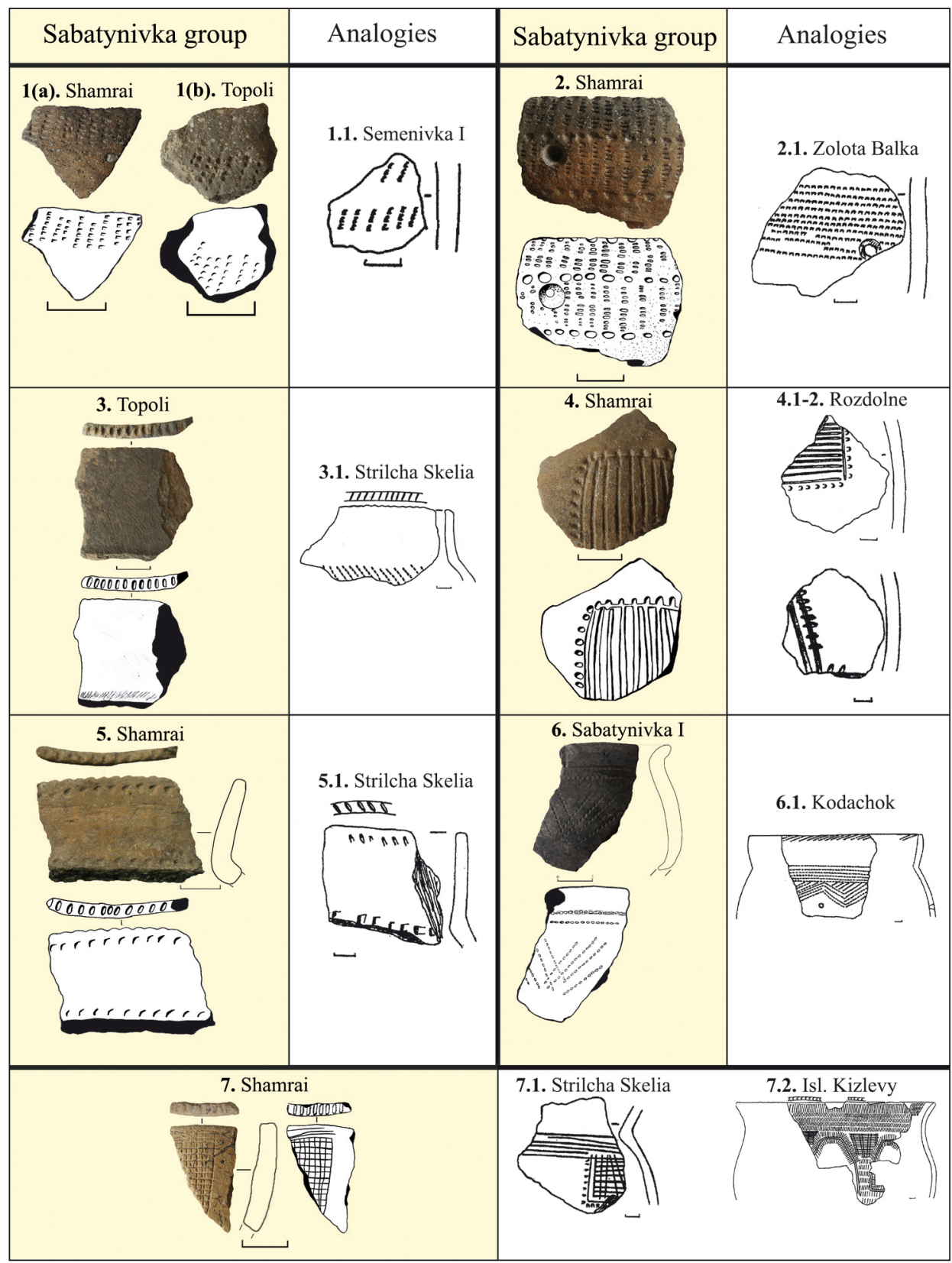

Fig. 4. Comparative table of Seredny Stog and Sabatynivka group pottery (analogies column by Kotova 2006) 
was lost due to post-depositional processes. A similar composition is known on beakers with high neck, well-visible shoulder and equal diameters of rim and bottom (PetrescuDîmbovița et al. 1999, 649). There is a potsherd with a surface fluted by wide flat grooves and black paint covering the space in-between in the collection of the Kamyane-Zavallia I site. This combination of flutes and black paint could be a late phenomenon (Popova 2003, 70).

Thus, the painted ware from the sites of the Sabatynivka group indicates their contemporaneity with Cucuteni A3 stage.

The third group of Sabatynivka ceramics is similar to the pottery of the mobile herders of the Pontic steppes that are included in the Skelia culture by Yu. Rassamakin (Rassamakin 2004) and represents the second stage of the Seredny Stog culture according to N. Kotova (Kotova 2008).

Most potsherds of the third group have a temper of crushed shells in their fabric. Some fragments have no such admixture, despite being ornamented in "Steppe" decorative style. The sherds have a layered structure in section. Their outer surfaces are well-smoothed, even and have red, reddish, reddish-grey, yellow-grey colour. The inner surfaces are less carefully finished; sometimes they bear traces of smoothing by a combed tool. This type of clay paste and surface finishing are uncommon in Trypillian contexts (Bem 2007, 58). The pottery of the first and the second groups contain fine mineral temper, barely visibly to the naked eye. The third group differs also from the shell-tempered pottery that is well-known from later contexts of Cucuteni-Trypillia cultural complex (Cucuteni C; Schmidt 1932). The surfaces of Cucuteni $\mathrm{C}$ ceramic are usually rough and not finely smoothed in contrast to the even surfaces of the third group of the Sabatynivka cultural complex.

There are rim fragments of pots of characteristic shape. The rims are straight or slightly projecting outwards. The necks are short and straight. They rise from rounded shoulders, with an abrupt transition between the shoulder and the neck. The rims are usually divided by evenly spaced cuts. This decoration can give them a "wavy" appearance. There is some decoration by combed stamp under the rim and below a transition to shoulders in most cases. This type of a vessel is typical for the ceramics of the Seredny Stog culture (Kotova 2008). In the latter case, they have rounded or pointed bases. No such bases were recovered from the five analysed sites of the Sabatynivka group. However, the upper parts and their decorations are almost identical. There are many fragments of this type in the collections of the Strilcha Skelia (third and fourth cultural layers), Semenivka I (IIIrd layer), Rozdolne (middle layer) and Seredny Stog II sites (Rassamakin 2004; Kotova 2008).

A fragment of a rounded shoulder is decorated with single imprints combined in a stripe with comb imprints (Fig. 4, 2). A hole was drilled in the fragment, probably in an attempted repair. It represents a pot of the shape described above, or very similar to the latter. There is an exact analogy in the site of Zolota Balka (Kotova 2006, fig. 26: 3). Numerous fragments of the walls of pots are decorated by vertical imprints of a combed tool organized in horizontal rows. They most probably come from vessels of the same type. Similar orna- 
mentation is typical for the Seredny Stog culture and is known from many settlements (Kotova 2006, 94, 109).

Some compositions consist of incised lines that are organized in a "hash-tag" pattern or filling a rhomboid surrounded by dots (Fig. 4: 4, 7). Similar decorations are known from the sites of Strilcha Skelia (third layer), Rozdolne (middle layer), Kyzlevy (Kotova 2006, fig. 17: 8; 26: 7; 32: 2; 33: 5).

A fragment of the upper part of a pot from Sabatynivka I site is decorated by stamped impressions (Fig. 4: 6). There are two horizontal stamped lines under the rim and diagonal intersecting stamped lines on the neck. It has no crushed shells in the ceramic fabric. The decoration resembles a vessel found in the site of Kodachok (third, or Stog phase of Seredny Stog culture; Kotova 2008, fig. 27: 1).

Summing up, the third group of the Sabatynivka ceramic complex finds closest analogies in the settlements of the second phase of the Seredny Stog culture or the Skelia cul-

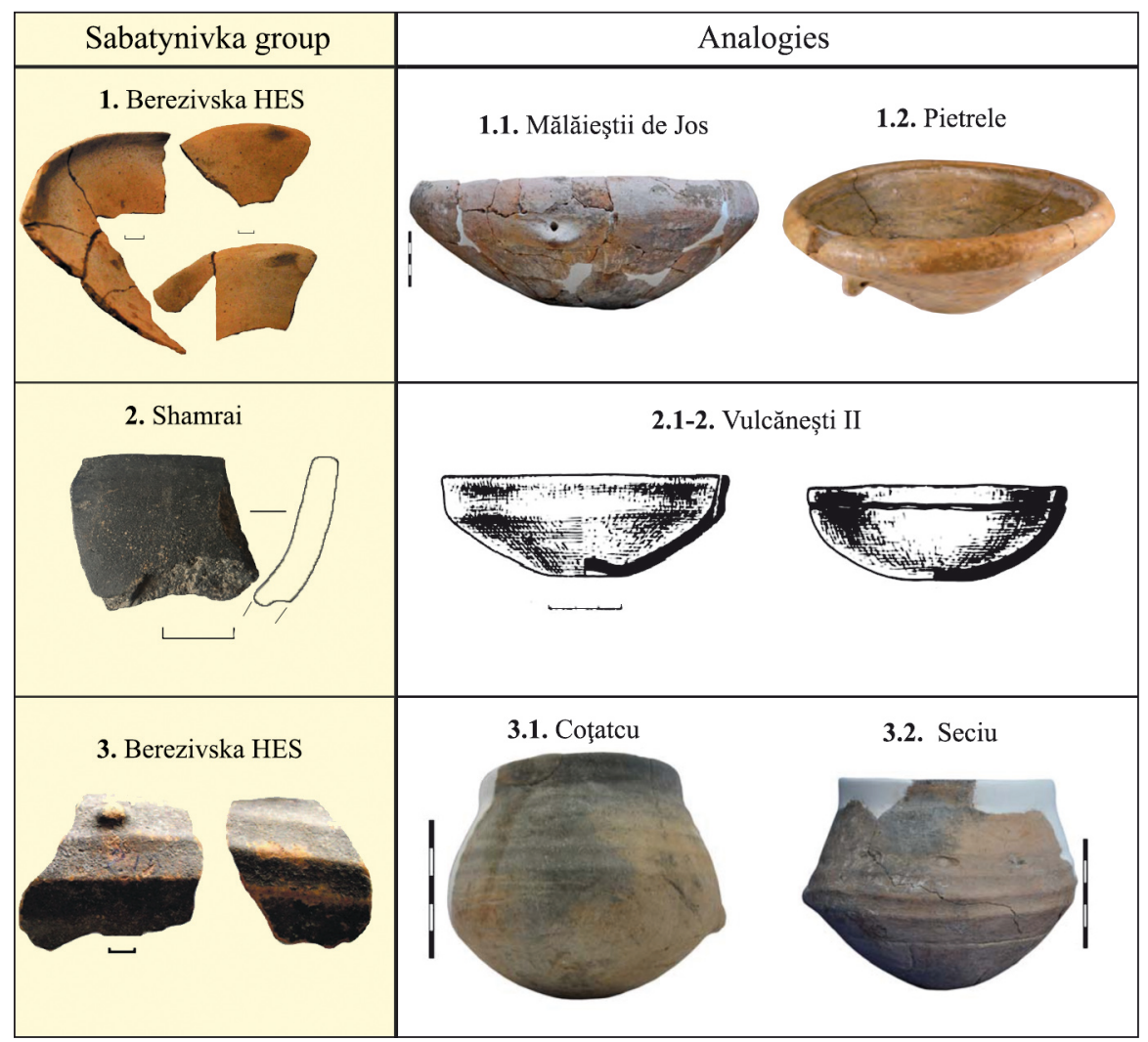

Fig. 5. Comparative table of Gumelnița (Bolgrad-Aldeni) and Sabatynivka group pottery (1, 3 by Burdo 2015, 1.1 by Hansen et al. 2011, 1.2, 3.1-2, 4.1 by Frînculeasa 2016, 2.1-2 by Beilekchi 1978, 4 by Kozubovskyi 1933) 
ture. Some elements are traceable to the third phase of the Seredny Stog culture or Stog culture. However, they are few and can be found also in the collections of the previous stage. Thus, en masse, the shell-tempered pottery of the Sabatynivka group was related to the ceramic complex of the mobile Steppe herders of the second-third stages of the Seredny Stog culture.

Another line of inquiry is represented by rare "imports" from the Gumelnița cultural area. There is an almost complete bowl found at the Berezivska HES settlement (Burdo 2015; Fig. 5: 1). It has a grey burnished outer surface and a characteristic conical profile, resembling to a great extent bowls known on the sites of Bolgrad (Bolhrad) - Aldeni aspect and on the sites of Gumelniţa itself. A fragment of grey burnished bowl was collected from the Shamrai site (Fig. 5: 2). It has a profile corresponding to the shapes of bowls from the sites of Bolgrad and Vulcăneşti II (Lower Danube region). Widely spaced nervures form the fluted surface of a yellow well-smoothed upper part of a thick-walled vessel (Berezivska HES - Fig. 5: 3). A similar decoration is well-known from the sites of Gumelnița as well as in Stoicani-Aldeni sites (Subbotin 1983; Hansen et al. 2006; 2009; 2012).

\section{DISCUSSION}

The radiocarbon dating has yielded contradictory results for the Sabatynivka group. The Kyiv dates place its existence in the timespan 4800-4400 BC, while the new AMS dates indicate it lasted from 4350 till 4250/4150 BC (Burdo 2015; Kiosak et al. 2021). Typological analysis of the ceramic complex has revealed links with surrounding cultures that could help to clarify the issue of chronology of the Sabatynivka group.

The chronology of Cucuteni A phase is far from being clear. The series of dates are overlapping and somewhat contradictory (Fig. 6). The "Kyiv" dating of Sabatynivka group is not relevant in the context of the absolute chronology of Romanian sites of Cucuteni A. It is obviously too early. They are contemporaneous with the available dates for the Precucuteni sites of Romanian Moldova (Rassamakin 2012). Meanwhile, the "AMS" ranges for the sites of the Sabatynivka group finds certain correspondence in the dataset for western part of the Cucuteni-Trypillia cultural complex (Mantu 1998; Lazarovici 2010). Namely, they are slightly later than Polyvaniv Yar III-1 (Trypillia B1), earlier dates for Scânteia (Cucuteni A3) and two earlier dates for the site of Putineşti III and could be synchronous with the site of Drăguşeni-Ostrov, other four dates for Scânteia, as well as sites of Leca Ungureni (A3), Preuteşti-Haltă (A3), Hăbăşeşti (A3), Cuconeştii Vechi (A3). The single date for the Dumeşti site (A3) is a little later than the AMS dates for the Sabatynivka group (Fig. 6). The data from the Sabatynivka group points to their probable co-existence in the $44^{\text {th }}$ to $42^{\text {nd }}$ centuries BC.

Shell-tempered pottery of the Sabatynivka sites is a direct analogy to the ceramic of the second stages of the Seredny Stog culture (the so called Skelia pottery). This cultural aspect 




Fig. 6. Comparison of selected ${ }^{14} \mathrm{C}$ dates for Cucuteni $\mathrm{A}$ and Sabatynivka group.

P3 - Putineşti III, DO - Drăguşeni-Ostrov, PH - Preuteşti-Haltă, CV - Cuconeştii Vechi, LU - Leca-Ungureni, H - Hăbăşeşti, D - Dumeşti, PY - Polyvaniv Yar, Sab-Kyiv: sum of radiocarbon dates obtained for the Sabatynivka group in Kyiv laboratory; Sab-AMS: sum of radiocarbon dates obtained for the Sabatynivka group by AMS dating; SI - Sabatynivka I, BH - Berezivska HES, KZI - Kamyane-Zavallia I, Sh - Shamrai 


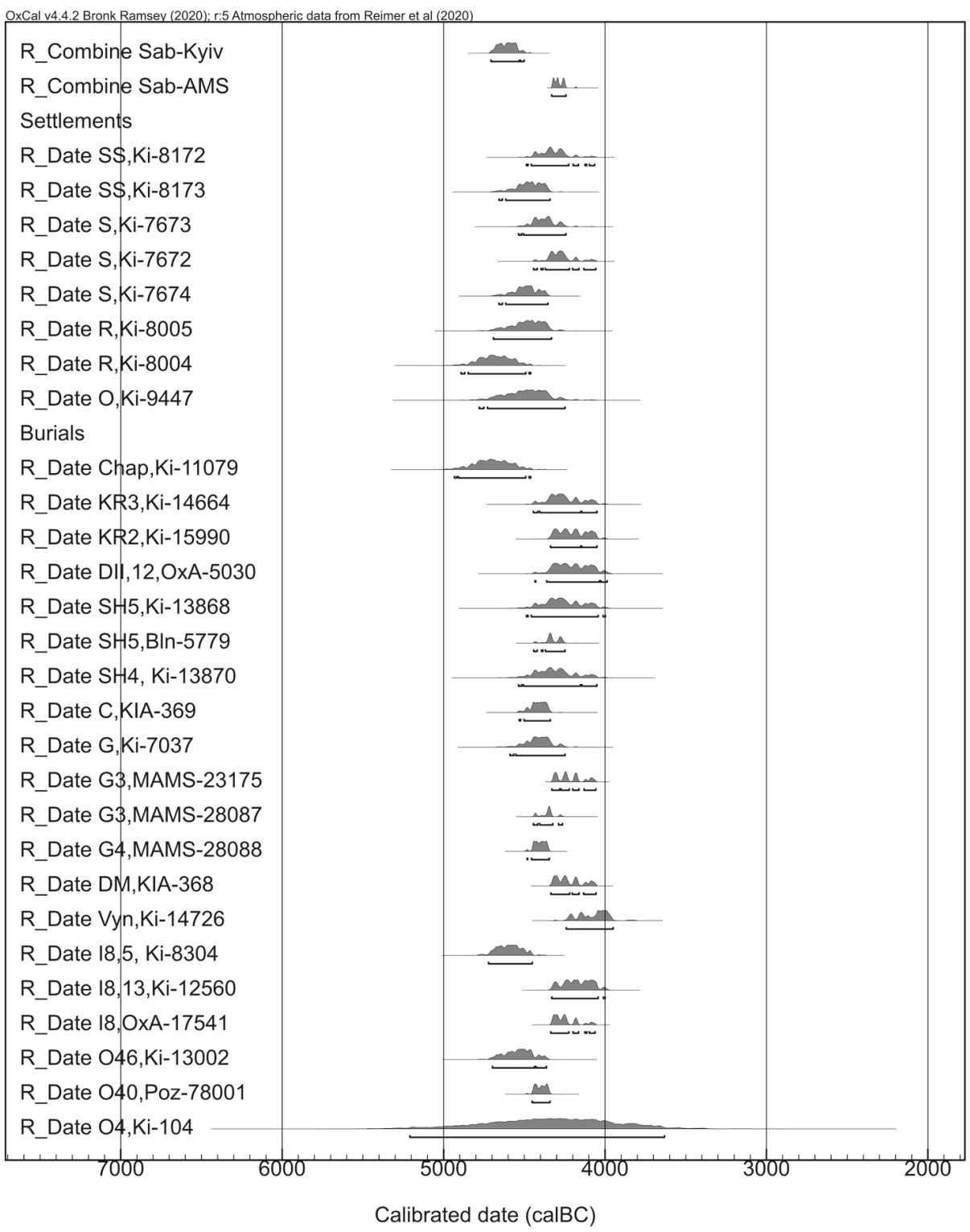

Fig. 7. Comparison of selected ${ }^{14} \mathrm{C}$ dates for Seredny Stog (Skelia and Stog phase) and Sabatynivka group. SS III I. - Strilcha Skelia, date Ki 8173 refers to layer III, date Ki-8172 refers to the fourth layer, S - Semenovka, layer III, R - Rozdolne, middle layer, O - Olexandria, Chap - Chapli, KR3 - Kryvyi Rih, b.3, KR2 Kryvyi Rih, b.2, DII, 12 - Dereivka II, b. 12, SH5 - Shakhtar 29/5, SH4 - Shakhtar 29/4, C - Căinari, G Giurgiulești, burials 3 and 4, DM - Decea Mureșului, b. 12, Vyn - Vynohradne 3/15, I8 - Ihren VIII, burials 5, 13 and 5a, O46 - Olexandrivsk, b. 46, O40 - Olexandria, burial 40, O4 - Olexandria, burial 4. Sab-Kyiv: combination of radiocarbon dates obtained for the Sabatynivka group in the Kyiv laboratory; Sab-AMS: combination of radiocarbon dates obtained for the Sabatynivka group by AMS dating 


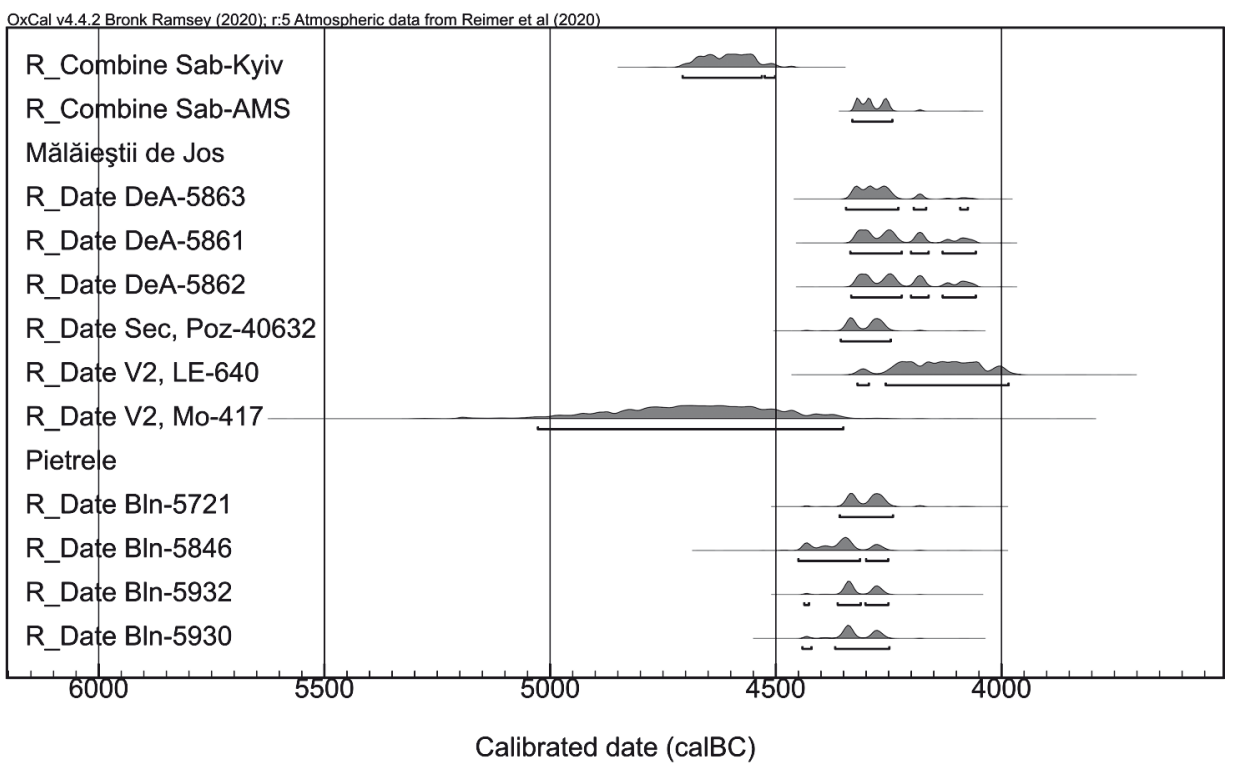

Fig. 8. Comparison of selected ${ }^{14} \mathrm{C}$ dates for Gumelnița (Bolgrad-Aldeni) and Sabatynivka group. Sec - Seciu, V2 - Vulcăneşti II; Sab-Kyiv: combination of radiocarbon dates obtained for the Sabatynivka group in the Kyiv laboratory; Sab-AMS: combination of radiocarbon dates obtained for the Sabatynivka group by AMS dating

has similar incongruences in chronology like the Sabatynivka group itself (Fig. 7). Skelia settlements are known from Dnieper Rapids region and Northern Azov Sea region. They were dated in the Kyiv laboratory to the timespan 4842-4242 calBC (20) (Kotova 2008). The dates for the $\mathrm{IV}^{\text {th }}$ layer of the Strilcha Skelia site, which belongs to another later phase (Stog; Kotova 2008), provides a terminus ante quem - 4488-4065 calBC (20). This dating corresponds with the chronological framework suggested for the Sabatynivka group by Kyiv dates.

However, it contradicts the series of dates obtained in other laboratories on burials of the Skelia phase, which are generally later. The burials are situated far away from settlements, in the areas inhabited mostly by bearers of other cultural aspects. The synchronism of settlements and burials was suggested by Yu. Rassamakin and developed by N. Kotova

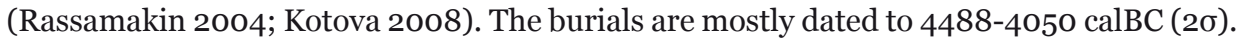
The only obvious outsider is Burial 46 from the Olexadrivsk necropolis (4698-4364 calBC - 20). An indicative case is the famous Giurgiuleşti cemetery. The first date for it encompassed 4588-4248 calBC (20). However, a more recent series of dates has helped to nar-

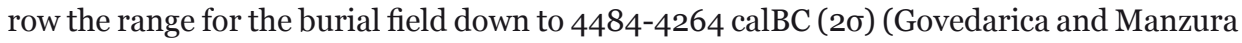
2016). A similar "drift" has happened to the Olexandria cemetery and is expected for the site of Chapli (Rassamakin 2017). The date for Vynohradne burial, which belongs to an- 
other later cultural tradition (Rassamakin 2009), provides a terminus ante quem (42413950 calBC - 20). Thus, while the dating of Skelia settlements requires re-analysis, the phenomenon of Skelia burials lasted also in $44^{\text {th }}$ to $42^{\text {nd }}$ centuries BC. The latter range is roughly corresponding to the "AMS" dating of Sabatynivka group.

The shell-tempered pottery was found at the sites of Bereşti (Cucuteni A3), Izvoare and Fedeleşeni in Romania (Bem 2007, 58) as well as at the sites of Druța I, Duruitoarea Nouă, Nezvisko, Jura, Polyvaniv Yar III-1 (Moldova and Ukraine; Palaguta 1998; Popova 2003). The chronology of Cucuteni stage A3 was discussed above. The Romanian researchers call these finds a "Cucuteni C" type of pottery, linking it with a characteristic ceramic of the later phases of Cucuteni A-B and B (Bem 2007, 58). However, from the point of view of the classification of Seredny Stog pottery, the "typical" shell-tempered ceramic differs from the potsherds found on the sites of Trypillia B1 (Tsvek and Rassamakin 2001-2002; Reingruber and Rassamakin 2016), including the sites of the Sabatynivka group. The latter resembles mostly Skelia pottery with some components of the next stage of Seredny Stog culture development, namely the Stog phase.

It is interesting that roughly the same can be said about the shell-tempered pottery found in Gumelnița culture contexts. It finds close analogies in the complexes of Skelia phase (or separate culture) and is securely dated in the contexts of Pietrele settlement to the time slot of 4450/4350-4270/4260 BC, with a particular emphasis on the second half of the $44^{\text {th }}$ century (Reingruber and Rassamakin 2016, 285, 286). A vessel of another type (with a pointed bottom and stamp decoration) comes from a context dated to the time after 4300 BC (Reingruber and Rassamakin 2016, 287). Thus, the dates of Skelia pottery in the Danube valley and on the Southern Buh river are roughly synchronous.

Gumelnița was recently dated to 4600-4250 BC (Hansen et al. 2012; Reingruber 2012; Reingruber and Rassamakin 2016). There is a hypothesis of its prolonged existence based on the dates from the sites of the Lower Danube basin (Manolakakis 2017). The earlier stages of Gumelnița bear evidence of interaction with the people of the Precucuteni Culure (Trypillia A), which existed prior to development of Cucuteni A - Trypillia B1 (Sorochin 2001). Thus, the earliest dates for Gumelnița A1 (4600-4450 BC; Reingruber and Rassamakin 2016) should be excluded from our consideration. The Trypillia B1 wares were found in the contexts of later phases of Gumelnița - stages A2-B1 (Frînculeasa 2016; Reingruber and Rassamakin 2016). A profound Trypillian impact is recorded on the sites of a particular variant of the Gumelnița cultural block, namely the sites of the so-called Bolgrad-Aldeni or Stoicani-Aldeni aspect (Sorochin 2001). It was suggested that the latter represents a local variant of the Gumelnița A1 phase. However, there were some imports of Trypillia B1 wares in the Bolgrad-Aldeni sites of Taraclia I and Novoselske I (Subbotin 2013, 113). The recent radiocarbon dates from north Muntenia indicate that the later phases of Stoicani-Aldeni cultural aspect could have co-existed with the phase of Gumelnița A2 and with Cucuteni A3 (Frînculeasa 2016). Some of the dates that were obtained from Bolgrad-Aldeni sites are in good correspondence with "AMS" chronology of the Sabatynivka 
I group, thus reinforcing the possibility of their coexistence that comes from the typological analysis of "imports". Thus, the dates for the Gumelnița culture and Bolgrad-Aldeni aspect are likely to contradict the "Kyiv" chronology of the Sabatynivka group, while they are in good correspondence with the "AMS" set of dates.

We should take into account the dating of the Early Trypillia sites situated in the same microregion with the Sabatynivka group. There are nine known sites (Peresunchak 2012). Some are situated just in 5-10 km from the sites of Berezivs'ka HES and Sabatynivka I. Two sites were dated by AMS approach: Mohylna III and Mohylna V (Kiosak et al. 2021). The dates encompass 4677-4466 calBC (20). So far no numerous early Trypillian components have ever been noted in the collections of the Sabatynivka group sites (Burdo 2015). So, we suppose that the dating of the Mohylna sites represents a terminus post quem for the Trypillia B1 sites of the region. This excludes effectively the first half of the fifth millennium from the timespan of their existence. Painted pottery bearers had likely penetrated the region after 4500 calBC and, in fact, there is a certain gap between available the AMS dates for the Early Trypillian sites and the Sabatynivka group settlements.

The new chronology places the Sabatynivka group into another environmental context. The Kyiv dates suggested its development during the Holocene climatic optimum. Meanwhile, new dating demonstrates that the sites of the Sabatynivka group existed till the very beginning of the climatic phase $\mathrm{hl}_{\mathrm{b}-6}$ by M. F. Veklych (1987). Based on the pollen cores and soil sequences from Central Ukraine, N. Herasimenko describes this period as the time of a notable aridization in the steppe, the reduction of deciduous woods, and the disappearance of hornbeam (Herasimenko 2004, 23). It is a phase of a slow trend towards even more arid climate and grassland expansion in the IV millenium BC (Herasimenko 2004, 23, 24).

It is interesting that dense settlement of the Sabatynivka microregion started with the Linear Pottery culture (four sites; Kiosak 2017; Kiosak and Salavert 2018), continued via Trypillia A (nine sites; Peresunchak and Burdo 2015; Peresunchak 2018), till the Trypillia B1 period (eight sites;Burdo 2015). However, there is a sharp decrease in the sites of the later phases of Trypillia. Trypillia B1-2 was attested by a small collection of potsherds at the multi-layered site of Melnychna Krucha (Kiosak and Salavert 2018; Salavert et al. 2021). The B2 phase is known at the site of Hetmanivka, some $15 \mathrm{~km}$ to south of the Sabatynivka I site (Kiosak et al. 2014) and the Late Trypillia sites are absent in the microregion. Maybe the climatic instability of the late fifth millennium $\mathrm{BC}$ is to be blamed for this shift of the occupation intensity?

\section{CONCLUSIONS}

Thus, combining various lines of enquiry, we can conclude that the Sabatynivka group existed in the $44^{\text {th }}$ to the $42^{\text {nd }}$ centuries BC. The sites of the Sabatynivka group have produced evidence for intercultural contacts in many directions. It seems that the Sabatynivka 
group was partially synchronous with the Skelia phase of the Seredny Stog culture, Cucuteni A3 and Gumelnița A2-B1. These lively connections made the Southern Buh valley an intersection point for different influences and cultural and social impulses, an ideal environment for social innovations.

The sites of the Sabatynivka group can be helpful in the synchronization of the Steppe cultural groups that occupied the Dnieper Rapids region and eastwards, with the archaeological record of the region between the Carpathians and the Dniester and Danube rivers. In particular, the combination of Skelia ceramic ware and the Cucuteni A painted pottery in the pit at the site of Shamrai could be a reference point to link and date these two phenomena.

The Skelia ware was the first "steppe-influenced" pottery to enter the Cucuteni-Trypillia archaeological record (Tsvek and Rassamakin 2001-2002; Reingruber and Rassamakin 2016). By 4350-4250 BC, it co-existed with some elements of the Stog ware. The potsherds with "steppe influence" from the Sabatynivka group differ from the well-known ware of Cucuteni $\mathrm{C}$ type, which is usually found in the settlements of Trypillia B1-B2 and later periods. The latter resembles ceramics of the Stog phase of the Seredny Stog culture, but mostly - vessels of the Dereivka culture of the middle Aeneolithic (Kotova 2013). The "steppe" component of the Sabatynivka I ceramic assemblage parallels the earlier Skelia ware. Thus, we can assume that the different stages of the Trypillia phenomenon were marked by contacts with various steppe groups. The establishment of these "partnerships" is a separate task, which cannot be solved from ad hoc ideas about cultural development, but requires empirical evidence in the archaeological record for every event of interaction.

So, the sites of the Sabatynivka group were settled during a chronological stage recorded in many regions (Manzura 2000; Govedarica 2004; Kotova and Videiko 2004; Rassamakin 2004; Videiko 2004; Manzura 2005; Reingruber 2012; Subbotin 2013; Govedarica and Manzura 2016; Reingruber and Rassamakin 2016) and which is characterized by the co-existence of the Skelia phase of the Seredny Stog culture, burials of Novodanylivka type, Cucuteni A3 (Trypillia B1) and Gumelnița A2. It seems that the end of this chronological stage was also the end of the Sabatynivka group. This event of broad historical significance most likely occurred around 4250/4150 BC, at least in the Southern Buh valley. The event corresponds with the beginning of a pronounced aridisation of the steppe (Herasimenko 2004). Thus, we can suppose that environmental pressure was partially responsible for the demise of the Sabatynivka group.

\section{Acknowledgements}

The radiocarbon dating of the sites of the Sabatynivka group was supported by SNF SCOPES grant, Project IZ73Zo_152732. The interpretation of data was developed thanks to funding from the European Union's Horizon 2020 research and an innovation programme under the Marie Skłodowska-Curie grant agreement No 891737. 


\section{References}

Beilekchi V. S. 1978. Ranniy eneolit nizov Pruta i Dunaya (Gumelnitske poseleniya Vulkaneshty II i Lopatsika v iuzhnoy chaste Moldavskoy SSR). Kishinev: Shtiintsa.

Bem C. 2007. Traian - Dealul Fântânilor. Fenomenul Cucuteni A-B. Târgovişte: Editura Cetatea de Scaun.

Burdo N. 2015. Mesto pamiatnikov sabatinovskogo tipa v strukture kulturnogo kompleksa KukuteniTripolie. Materialy po arkheologii Severnogo Prichernomoria 13, 11-26.

Burdo N. B. 2003. Novye dannye dla absolutnoy datirovki neolita i rannego eneolita na territorii Ukrainy. Stratum Plus, 431-446.

Chapman J., Gaydarska B. and Nebbia M. 2019. The Origins of Trypillia Megasites. Frontiers in Digital Humanities 6/10.

Chernish E. K. 1982. Eneolit Pravoberezhnoi Ukraini. In V. M. Masson and N. I. Merpert (ed.), Eneolit SSSR. Moscow: Nauka, 166-347.

Dębiec M., Kiosak D., Pelisiak A., Posselt M., Saile T., Tkachuk T. and Țerna S. 2014. Geomagnetic Prospection on Tripillian Sites in Central Ukraine. In Gh. Dumitroaia, C. Preoteasa and C.-D. Nicola (eds), Cucuteni Culture within the European Neo-Eneolithic Context. International Colloquium. Cucuteni - 13o. Abstracts. Piatra-Neamț: Editura “Constantin Matasă”, 72-73.

Dobrovolskyi A. V. 1952. Persche Sabatynivske poselennia. Arkheologichni pamiatky URSR 4, 78-83.

Dumitrescu V. 1. 1963a. Originea şi evoluția culturii Cucuteni-Tripolye (I). Studii şi Cercetări de Istorie Veche 14/1, 51-74.

Dumitrescu V. l. 1963b. Originea şi evoluția culturii Cucuteni-Tripolye (II). Studii şi Cercetări de Istorie Veche 14/2, 285-308.

Frînculeasa A. 2016. Nordul Munteniei şi cronologia aspectului cultural Stoicani-Aldeni - stratigrafie, elemente de reper şi date radiocarbon din situl de la Mălăieştii de Jos (jud. Prahova). Buletinul Muzeului Județean Teleorman. Seria Arheologie 8, 59-107.

Gaskevych D. L. 2013. V. M. Danilenko ta periodyzatsiya neolitu Pivdennogo Bugu; novi zapytannia do starikh dzherel. Arkheologiya 4/2013, 3-17.

Gaskevych D. L. 2014. Problemy radiovugletsevogo datuvannia bugo-dnistrovskoyi neolitychnoyi kultury. Arkheologiya 1.

Gaydarska B., Nebbia M. and Chapman J. 2020. Trypillia Megasites in Context: Independent Urban Development in Chalcolithic Eastern Europe. Cambridge Archaeological Journal 30/1, 97121.

Govedarica B. 2004. Zepterträger - Herrscher der Steppen. Die frühen Ockergräber des Äneolithikums im karpaten-balkanischen Gebiet und im Steppenraum Südost- und Osteuropas. Mainz: Philippe von Zabern.

Govedarica B. and Manzura I. V. 2016. The Giurgiulești Cemetery in Chronological and Cultural Context of Southeastern and Eastern Europe. Eurasia Antiqua 22, 1-39.

Hansen S., Dragoman A., Reingruber A., Gatsov I., Klimscha F., Nedelcheva P., Song B., Wahl J. and Wunderlich J. 2006. Pietrele - eine kupferzeitliche Siedlung an der Unteren Donau. Bericht uber die Ausgrabung im Sommer 2005. Eurasia Antiqua 12, 1-62. 
Hansen S., Toderas M., Reingruber A., Becker N., Gatsov I., Kay M., Nedelcheva P., Prange M., Ropke A. and Wunderlich J. 2009. Pietrele: der kupferzeitliche Siedlunghugel „Magura Gorgana“ und sein Umfeld. Bericht uber die Ausgrabung und geomorphologischen Untersuchengen im Sommer 2008. Eurasia Antiqua 18, 1-66.

Hansen S., Toderas M., Reingruber A., Wunderlich J., Benecke N., Gatsov I., Marinova E., Muller M., Nachev C., Nedelcheva P., Nowacki D., Ropke A., Wahl J. and Zauner S. 2012. Pietrele an der Unteren Donau. Bericht uber die Ausgrabung im Sommer 2011. Eurasia Antiqua 18, 1-68.

Herasimenko N. P. 2004. Rozvytok zonalnykh landshaftiv chenvertynnogo periodu na teritorii Ukrainy. Avtoreferat diss. doctora geographichnyh nauk. Kyiv.

Hofmann R., Müller J., Shatilo L., Videiko M., Ohlrau R., Rud V., Burdo N. B., Dal Corso M., Dreibrodt S. and Kirleis W. 2019. Governing Tripolye: Integrative architecture in Tripolye settlements. PLoS ONE 14/9, e0222243. DOI: 10.1371/journal.pone.0222243.

Kiosak D. 2016. „Stepoviy vpliv” ta pamiatki tipu Sabatynivka 1 (za materialamy poselennia Shamrai). Starodavnie Prichenomoria 11, 226-232.

Kiosak D. 2017. Kamyane-Zavallia, the eastermost Linear Pottery culture settlement ever excavated. Sprawozdania Archeologiczne 69, 253-270. DOI: 10.23858/SA69.2017.010.

Kiosak D. 2019. Attack and defence? New evidence for "Trypillia-Steppe" interaction in the valley of the Southern Bug River (Central Ukraine). Revista Arheologică. Serie noua 15/2, 14-28.

Kiosak D., Denisiuk V. L. and Polischuk L. I. 2014. Ornitomorfne briazkaltse trypilskoyi kultury z pivnochi Odeschyny. Arheologiya 3/2014, 67-72.

Kiosak D., Kotova N., Tinner W., Szidat S., Nielsen E., Brugger S., de Capitani A., Gobet E. and Makhortykh S. 2021. The last hunter-gatherers and early farmers of the middle Southern Buh river valley (Central Ukraine) in VIII-V mill. BC. Radiocarbon, 63/1, 121-137.

Kiosak D. and Salavert A. 2018. Revisiting the chronology of two Neolithic sites in Eastern Europe: new radiocarbon dates from Melnychna Krucha and Kamyane-Zavallia (Southern Buh region, Ukraine). Revista Arheologică. Serie noua 14/2 116-131.

Kotova N. S. 2006. Ranniy eneolit stepnogo Podneprovia I Priazovia. Lugansk: Vydavnytstvo SNU im. V. Dalia.

Kotova N. S. 2008. Early Eneolithic in the Pontic Steppes (= British Archaeological Reports 1735). Oxford: John and Erica Hedges Ltd. British Archaeological Reports.

Kotova N. S. 2013. Dereivska kultura i pamiatniki nizhnemikhailovskogo tipa. Kyiv - Kharkiv: Maidan.

Kotova N. S. and Videiko M. Y. 2004. The absolute chronology of Ukraine in Eneolithic. In B. Hänsel and E. Studeníková (eds), Zwischen Karpaten und Ägäis. Neolithikum und ältere Bronzezeit. Gedenkschrift für Viera Němejcová-Pavúková (= Internationale Archäologie. Studia Honoria 21). Rahden/Westf.: Verlag Marie Leidorf GmbH, 121-134.

László A. 1997. Datarea prin radiocarbon în arheologie (= Biblioteca Muzeului Național 2). Bucureşti. Lazarovici C. M. 2010. New data regarding the chronology of the Precucuteni, Cucuteni and Horodiştea-Erbiceni cultures. In J. Šuteková, P. Pavúk, P. Kalábková and B. Kovár (eds), PANTA RHEI. Studies on the Chronology and Cultural Development of South-Eastern and Central Europe in Earlier Prehistory Presented to Juraj Pavúk on the Occasion of his $75^{\text {th }}$ Birthday. Bratislava: Comenius University, 71-94. 
Lobanova M. A., Matviishyna Zh. M. and Kiosak D. 2021. The Issue of the Stratigraphy of the Site Sabatinovka I and the Enviromental Settings of the Southern Bug Region in the Eneolithic - Late Bronze Age. Stratum Plus, 2/2021, 31-52.

Manolakakis L. 2017. So long blades. In L. Manolakakis, N. Schlanger and A. Coudart (ed.), European Archaeology - Identities \& Migrations. Leiden: Sidestone, 265-284.

Mantu C. M. 1998. Cultura Cucuteni. Evoluție, cronologie, legături. Piatra-Neamț: Editura Nona.

Mantu C. M. 200o. Relative and Absolute Chronology of the Romanian Neolithic. Analele Banatului, S.N. 7-8, 75-106.

Manzura I. V. 2000. Vladeyushche skipetrami. Stratum Plus 2/2000, 237-295.

Manzura I. V. 2005. Steps to the Steppe: or, how the North Pontic Region was colonised. Oxford Journal of Archaeology 24/4, 313-338.

Mischka C., Preoteasa C. and Schafferer G. 2016 (2019). Gradiometerprospektionen auf Fundplatzen der Cucuteni-Kultur im Kreis Neamț (Rumänien). Eurasia Antiqua 22, 115-131.

Müller J., Hofmann R., Ohlrau R.and Shatilo M. 2018. The social constitution and political organisation of Tripolye mega-sites: hierarchy and balance. In H. Meller, D. Gronenborn and R. Risch (eds), Überschuss ohne Staat - Politische Formen in der Vorgeschichte. 10. Mitteldeutscher Archäologentag, 19-21 Oktober 2017 Halle (Saale)/Surplus without the state - political forms in Prehistory, 1oth Archaeological Conference of Central Germany,19-21 October 2017 Halle (Saale) (= Tagungen des Landesmuseums für Vorgeschichte Halle 18). Halle: Landesamt für Denkmalpflege und Archäologie Sachsen-Anhalt, 247-262.

Müller J. and Rassmann K. 2016. Introduction. In J. Müller, K. Rassmann and M. Videiko (eds), Trypillia Mega-Sites and European Prehistory: 410o-340o BCE. London and New York: Routledge, 1-5.

Palaguta I. 1998. K probleme sviazey Tripolia-Kukuteni s kulturami eneolita stepnoy zony Severnogo Prichernomoria. Rossiyskaya Arkheologiya 1/1998, 5-14.

Palaguta I. 2007. Tripolye Culture during the Beginning of the Middle Period (B1): The relative chronology and local grouping of sites. Oxford: Hadrian Books.

Palaguta I. 2016. Tripolskaya kultura $v$ nachale razvitogo perioda (BI): otnositelnaya khronologiya i lokalnye varianty pamiatnikov. Kyiv: Vydavets Oleh Filiuk.

Passek T. S. 1949. Periodizatsiya tripolskih poseleniy (III-II mill. BC). Moscow, Leningrad: MIA.

Peresunchak O. S. 2012. Novi tripilski poselennia na Pivdennomu Buzi. In V. V. Otroshchenko (ed.), Zemledeltsi iskotovodi drevney Evropi. Problemi, novye otkritia, hipotezi. Kyiv, Saint Petersburg: FOP Korvin-Piotrovskii A., 149-159.

Peresunchak O. S. 2015. Poselennia trypilskoii kultury Topoli. Materialy po arheologii Severnogo Prichernomoria 13, 155-158.

Peresunchak O. S. 2018. Novi pamiatky arkheologii v baseyni r. Mohylianka. In I. V. Nemchenko (ed.), Starodavne Prychornomoria. Odessa, 408-413.

Peresunchak O. S. and Burdo N. 2015. Kolektsia plastyky iz ranniotrypilskogo poselennia Mohylna III. In O. Diachenko, F. Menotti, S. Ryzhov, K. Buniatian and S. Kadrow (eds), Kul'turnyi kompleks Cucuteni-Trypillia ta yogo susidy. Zbirka naukovykh prats pamiati Volodymyra Krutsa. Lviv: Astroliabia, 357-366. 
Petrescu-Dîmbovița M., Florescu M. and Florescu A. C. 1999. Truşeşti. Monografie arheologică. Bucureşti, Iaşi: Editura Academiei Române.

Popova T. A. 2003. Mnogosloynoe poselenie Polivanov Yar. K evolitsii tripolskoi kultury $v$ Srednem Podnestrove. Sankt-Petersburg: MAE RAN.

Ramsey B. C. and Lee S. 2013. Recent and Planned Development of the Program OxCal. Radiocarbon 55/2-3, 720-730.

Rassamakin Yu. 2004. Die nordpontische Steppe in der Kupferzeit (= Archäologie in Eurasien 17). Mainz am Rhein: Verlag Philipp von Zabern.

Rassamakin Yu. 2012. Absolute chronology of Ukrainian Tripolian settlements. In F. Menotti and A. Korvin-Piotrovsky (eds), The Tripolie culture giant-settlements in Ukraine. Formation, Development and Decline. Oxford and Oakville: Oxbow books, 19-69.

Rassamakin Y.Y. 2009. Novye daty k absolutnoy khronologii epokhi eneolita stepnogo Prichernomoria (predvaritelnaya informatsiya). Archaeological Almanac 20, 289-296.

Rassamakin Y. Y. 2017. Mohylnyky Ihren (Ohrin) 8 ta Oleksandria doby eneolitu: problemy datuvannia ta kulturnoi nalezhnosti. Arkheologija 4, 26-48.

Reingruber A. 2012. Absolute and relative chronologies in the Lower Danube Area during the $5^{\text {th }}$ millennium BC. In S. Hansen, P. Raczky, A. Anders and A. Reingruber (ed.), Neolithic and Copper Age between the Carpathians and the Black Sea. Bonn: Dr. Rudolf Habelt Verlag, 301-324.

Reingruber A. and Rassamakin Yu. Ya. 2016. Zwischen Donau und Kuban: Das nordpontische Steppengebiet im 5. Jt.v. Chr. In V. Nikolov and W. Schier (ed.), Der Schwarzmeer Raumvom Neolithikum bis in die Früheisenzeit (6ooo-60o v. Chr.): Kulturelle Interferenzen in der zirkumpontischen Zone und Kontakte mit ihren Nachbargebieten. Rahden-Westf.: Verlag Marie Leidorf GmbH, 273-311.

Saile T., Posselt M., Debiec M., Kiosak D. and Tkachuk T. 2016a. Prospections magnétometriques sur des sites de la culture Cucuteni - Trypillia sur le course du Dniestre et du Boug de Sud. C. Preoteasa and C. D. Nicola (eds), Cucuteni Culture within the European Neo-Eneolithic Context. Proceedings of the International Colloquium „Cucuteni - 130”, 15-17 October 2014, Piatra-Neamț, Romania/ In Memoriam Dr. Dan Monah/In Memoriam Dr. Gheorghe Dumitroaia. Piatra-Neamț: Editura „Constantin Matasă”, 581-96.

Saile T., Posselt M., Dębiec M., Kiosak D. and Tkachuk T. 2016b. Zwei Magnetometerprospektionen auf ukrainischen Fundstellen des Cucuteni-Tripolje-Komplexes an Dnjestr und südlichem Bug. Archäologisches Korrespondenzblatt 46, 465-77.

Salavert A., Gouriveau E., Messager E., Lebreton V. and Kiosak D. 2021. Multi-proxy Archaeobotanical Analysis from Mesolithic and Early Neolithic Sites in South-west Ukraine. Environmental Archaeology 26/3, 349-362.

Schmidt H. 1932. Cucuteni in der oberen Moldau, Rumänien: die befestigte Siedlung mit bemalter Keramik von der Steinkupferzeit bis in die vollentwickelte Bronzezeit. Berlin-Leipzig: W. de Gruyter.

Sorochin V. 2001. Relațiile între culturile Precucuteni-Tripolie A şi Bolgrad-Aldeni. Tyragetia 10, 81-90.

Sorochin V. 2002. Aspectul regional cucutenian Drăguşeni-Jura. Piatra-Neamț: Editura “Constantin Matasă". 
Stanko V. N. and Smolianinova S. P. 1974. Razvedki v Savranskov i Liubashevskom raionah Odesskoi oblasti in 1974. Archive Odessa Archaeological Museum: unpublished. Odessa.

Subbotin L. V. 1983. Pamitniki kultury Gumelnita yugo-zapada Ukrainy. Kyiv: Naukova dumka.

Subbotin L. V. 2013. Kultura Gumelnita: bolgradskiy variant. In I. V. Bruiako and T. L. Samoilova (eds), Drevne kultury Severo-Zapandnogo Prichernomoria. Odessa: SMIL, 85-114.

Telegin D. Y. 1986. Dereivka. A Settlement and Cemetery of Copper Age Horse Keepers on the Middle Dnieper (= BAR International Series 287). Oxford: British Archaeological Reports.

Telegin D. J. 1987. Neolithic cultures of the Ukraine and adjacent areas and their chronology. Journal of World Prehistory 1/3, 307-331.

Tsvek E. and Rassamakin Yu. Ya. 2001-2002. Poselene vostochnotripolskoy kultury Miropole i problema otnositelnoi khronologii pamiatnikov tipa Srednyi Stog 2. Stratum Plus 2, 218-245.

Tsvek O. V. 1999. Novi doslidzhennia bagatosharovogo poselennia shidnotrypilskoyi kultury Berezivka na Pivdennomu Buzi. Arheologichni vidkryttia v Ukraini 1998-1999 rr., 51-53.

Tsvek O. V. 2004. Berezivka (Berezivska HES). In M. Y. Videiko, N. Burdo and S. M. Liashko (eds), Entsyclopedia trypilskoyi tsivilizatsii. Kyiv, 38-39.

Tsybeskov V. 1965. Nakhodka raspisnoi keramiki tipa Krish na Iuzhnom Buge. Kratke soobshcheniya o polevykh arkheologicheskikh issledovaniyakh Odesskogo gosudarstvennogo arkheologicheskogo muzeya, 42-44.

Veklych M. F. 1987. Problemy paleoklimatologii. Kyiv: Naukova dumka.

Videiko M. Y. 2004. Periodyzatsiya trypilskoyi kultury. In M. Y. Videiko and N. Burdo (eds), Entsyclopedia trypilskoyi syvilizatsii 1. Kyiv, 77-84.

Videiko M. Y., Chapman J., Burdo N., Gaydarska B., Terna S., Rud V. S. and Kiosak D. 2015. Kompleksnye issledovania oboronitelnykh sooruzheniy, proizvodstvennykh kompleksov i ostatkov postroek na tripolskom poselenii u sela Nebelevka. Stratum Plus 2/2015, 147-170.

Yakovyshyna Ja. and Kutseniak O. 2016. Keramichnyi kompleks trypilskoho poselennia Nezvysko z rozkopok L. Kozlovskoho: proba systematyzatsii. Materialy i doslidzhennia z arkheolohii Prykarpattia i Volyni 20, 57-68.

Zbenovich V. G. 1996. Siedlungen den frühen Tripol'e-Kultur zwischen Dnestr und Südlichem Bug. Espelkamp: Verlag Marie Leidorf $\mathrm{GmbH}$. 